\title{
STUDI KARAKTERISTIK WISATAWAN DAN UPAYA PENGEMBANGAN PRODUK WISATA TEMATIK DI PANTAI GOA CEMARA, PANTAI KUWARU, DAN PANTAI PANDANSIMO BARU KABUPATEN BANTUL
}

\author{
Fian Damasdino \\ Dosen Sekolah Tinggi Pariwisata AMPTA Yogyakara email: fiandamdin@gmail.com
}

\begin{abstract}
This research is a quantitative research using survey method. The locations of the research are in the three tourist objects including Goa Cemara Beach, Kuwaru Beach, and Pandansimo Baru Beach. This study aims to analyze the tourist characteristics in the three research location and to learn how to formulate a plan for the most appropriate for tourism products at three locations sights. The approach used to analyze the tourist characteristics is the four elements of market segmentation: geographic, sociodemographic, psychographic, and behavioral.

The samples of the research are 156 respondents with the margin of error $8 \%$ done using purposive sampling technique during March to April 2015 in the three research locations. The data collection was taken by questionnaires, observation, and documentation. Once the data is collected and processed with quantitative analysis using statistical tools, frequency distribution, and cross table (crosstabs).

The result shows that the geographic characteristics of tourists in the three locations are balanced between tourists from outside and inside Bantul Regency. Then, the sociodemographic characteristics of tourists in Goa Cemara Beach and Pandansimo Baru Beach are dominated by private employees/BUMN(state-owned corporation), aged 22-60 years old, married and repeater tourist, while tourists in Kuwaru Beach are dominated by students, under 22 years old, single status and first comer tourists.

Furthermore, in terms of psychographics, tourists in the three locations who have psychocentric characteristics prefer to get something plural, popular, and like to do common activities with the frequency of short stay visit. Lastly, the behavior of tourists in the three research locations is dominated by doing recreation or having leisure time to enjoy the main attractions of coastal landscape. The results of tourist characteristics of these three locations are used as the basis for planning of thematic tourism products in accordance with the character of the three research objects.
\end{abstract}

Keywords: tourist characteristics, tourist segmentation, geographic, sociodemographic, psychographic, behavioral

\section{PENDAHULUAN}

Perkembangan dunia pariwisata yang secara signifikan beberapa tahun terakhir mempunyai dampak pada perkembangan perekonomian suatu negara. Selain peningkatan devisa negara, pariwisata juga berperan dalam bentuk perluasan lapangan kerja, peningkatan pertumbuhan ekonomi, peningkatan kesejahteraan masyarakat, kemiskinan, dan pemerataan pembangunan spasial. Pariwisata muncul sebagai salah satu kekuatan dan harapan bagi pemulihan 
kembali pembangunan nasional (Hendrie dalam Fandeli, 2000:33).

Perkembangan pariwisata di Yogyakarta cukup pesat selama 5 tahun terakhir. Hasil survei tahunan tentang pasar wisata DIY ke beberapa kota se- Jawa sejak 2009 menyebutkan study tour ke Yogyakarta sebagai pilihan utama di luar Jakarta dan Bali (Opini Harian Kedaulaatan Rakyat, tanggal 20 Juni 2012). Hal ini tentu sejalan dengan Perda No 1 Tahun 2012 tentang Rencana Induk Pembangunan Kepariwisataan Daerah (RIPPDA) DIY 2012-2025. Yogyakarta berusaha menjadi destinasi wisata yang terkemuka, berkelas dunia, berdaya saing, berwawasan budaya, berkelanjutan, mampu mendorong pembangunan daerah dan pemberdayaan masyarakat.

Daerah Istimewa Yogyakarta (DIY) berusaha menjadi "MICE City" yang menitikberatkan kepada aktivitas Meeting, Incentive Tour, Conference, dan Exhibition. Pembangunan hotel sebagai salah satu akomodasi serta berbagai mana fasilitas yang sekiranya menunjang yang mempengaruhi sektor pariwisata terus menerus dilakukan di Yogya. Tercatat pada tahun 2013 terdapat penyelenggaraan 13.695 MICE di hotel berbintang DIY. Jumlah ini meningkat $6,13 \%$ dibandingkan tahun sebelumnya (RKPD DIY, 2014:185). Selain ketersediaan infrastruktur hotel dan ruang pertemuan, fasilitas-fasilitas pelayanan publik seperti jalan, transportasi massal dalam kota, bandara baru, penataan stasiun, dan penataan obyek wisata telah dipersiapkan sejak dini. Pembangunan berbagai macam fasilitas tersebut ternyata tidak hanya di pusat kota dan wilayah Yogya bagian utara (Kabupaten Sleman). Wilayah Yogya bagian selatan yang berbatasan langsung dengan Samudra Hindia meliputi Kabupaten Gunungkidul, Bantul, dan Kulonprogo mulai menggeliat sektor pembangunannya. Berbagai infrastruktur baik skala besar (nasional/pusat) maupun daerah dibangun sedemikian rupa. Aktivitas pariwisata yang selama ini menjadi denyut nadi wilayah selatan DIY yang meliputi Kabupaten Gunungkidul, Kabupaten Bantul, dan Kabupaten Kulonprogo terus berkembang pesat.

Visi Gubernur DIY Sri Sultan HB X dalam RPJMD 2012-2017 dengan tema Yogyakarta menyongsong peradaban baru dengan membalik paradigma "among tani menjadi dagang layar" yang konsekuensinya laut selatan tidak lagi ditempatkan sebagai halaman belakang melainkan menjadi halaman depan menjadi perhatiannya. Makna dari paradigma tersebut pada dasarnya menghadapkan DIY ke arah selatan dilakukan melalui pengembangan wilayah pesisir secara terpadu (RKPD DIY, 2014: 96).

Adanya proyek pembangunan Jalur Jalan Lintas Selatan (JJLS) yang sedang dibangun di kawasan Pantai Selatan Yogyakarta yang melewati tiga kabupaten di DIY (Gunungkidul, Bantul, Kulonprogo) mendukung arah kebijakan rencana pengembangan kawasan pesisir pantai selatan DIY. Jalan tersebut ke depan diproyeksikan menjadi jalan nasional yang menghubungkan Cilacap-Banyuwangi pada tahun 2025. Pembangunan Jalur Jalan Lintas Selatan (JJLS) di wilayah DIY sendiri dibangun sepanjang 117,60 km yang akan menghubungkan semua garis pantai di DIY mulai ujung barat Kabupaten Kulonprogo yang berbatasan dengan Kabupaten Purworejo hingga ke ujung timur Gunungkidul yang berbatasan langsung dengan Kabupaten Wonogiri Jawa Tengah.

Selain itu, potensi besar yang memanfaatkan potensi adanya pembangunan Jalur Jalan Lintas Selatan (JJLS) antara lain adalah kemudahan aksesibilitas wisata di obyek wisata di sepanjang pantai selatan DIY, pembangunan bandara baru Yogyakarta (rencana dibangun di daerah Paliyan, Temon, Kab. Kulonprogo), dan pembangunan pelabuhan perikanan Tanjung 
Adikarto (samping Pantai Glagah). Hal tersebut tentu mempengaruhi aktivitas pariwisata dan perekonomian masyarakat di sepanjang pantai selatan Yogyakarta.

Kabupaten Bantul sebagai salah satu kabupaten di DIY yang berbatasan langsung dengan Samudra Hindia memiliki potensi yang sangat besar di bidang pariwisata. Sektor pariwisata merupakan salah satu sektor strategis di Kabupaten Bantul. Selain sebagai lokomotif penggerak peningkatan perekonomian masyarakat, sektor ini juga memberikan kontribusi terhadap Pendapatan Asli Daerah (PAD).

Jumlah kunjungan wisatawan ke Kabupaten Bantul pada tahun 2014 mencapai 2.298.351 orang, meningkat dari tahun 2011 sebanyak 1.740.417 orang. Sedangkan dari sisi kontribusi PAD pada tahun 2014 mencapai Rp 9.767.144.025, meningkat drastis dari perolehan tahun 2011 sebesar Rp 5.289.407.718,00 (Disbudpar Bantul, 2014). Peningkatan tersebut di atas selain didukung oleh keanekaragaman obyek wisata yang meliputi obyek wisata alam, budaya/religius, dan minat khusus/buatan, juga didukung oleh pengembangan desadesa wisata sebagai alternative tourism di Kabupaten Bantul, sehingga dapat memberikan pilihan-pilihan destinasi wisata bagi wisatawan.

Salah satu masalah yang dihadapi obyek wisata yang berupa pantai di selatan DIY dan Bantul khususnya adalah kondisi alam yang kurang menguntungkan. Karakteristik pantai selatan di Jawa secara umum yang didominasi oleh gelombang besar dan arus angin yang kuat dapat berdampak buruk pada berkurangnya areal daratan akibat abrasi (erosi pantai). Ada banyak pantai yang berderet memanjang dari timur ke barat hingga muara Sungai Progo yang berbatasan langsung dengan Samudra Hindia. Ada Pantai Parangtritis, Pantai Parangkusumo, Pantai Depok, Pantai Goa Cemara, Pantai Kuwaru, dan Pantai Pandansimo Baru.
Selama ini pantai-pantai tersebut menjadi penyumbang retribusi paling besar ke Kabupaten Bantul.

Mulai tahun 1998 digalakkan besarbesaran penanaman pohon Cemara Udang (Casuarina Equessetifolia) di sepanjang pesisir pantai mulai Pantai Depok ke barat hingga Pantai Pandansimo di tepi muara Sungai Progo (Windyanti,

2013:4). Deretan pohon cemara udang tersebut selain bermanfaat buat ekosistem pantai sebagai penahan abrasi dan arus angin ke daratan, ternyata bermanfaat juga bagi sektor pariwisata. Akhirnya, pada tahun 2010 dibukalah secara hampir bersamaan tiga pantai wisata yang ekosistemnya mirip, didominasi rerimbunan pohon cemara udang, Pantai Goa Cemara, Pantai Kuwaru, dan Pantai Pandansimo Baru.

Sebagai arah/panduan bagi pengembangan ketiga pantai tersebut sudah tertuang dalam RIPPDA DIY yang terbaru. RIPPDA DIY 2012-2017 direncanakan sebagai arah pembangunan ketiga pantai itu. Pasal 19 ayat 9d disebutkan dengan jelas bahwa ketiga pantai tersebut ditetapkan sebagai kawasan wisata berbasis keluarga dan pendidikan (RIPPDA DIY, 2012:22).

Melihat besarnya aktivitas pariwisata di tiga obyek wisata tersebut penulis merasa perlu penelitian lebih lanjut untuk melakukan analisis terhadap karakteristik pengunjung/wisatawanyangdatang. Rencana pengembangan pariwisata yang sudah tertuang di RPJMD, RKPD dan RIPPDA harus didukung oleh data riset yang kuat yang dijadikan basis/acuan pengembangan pariwisata daerah lebih lanjut. Penelitian ini menitikberatkan pada analisis pengunjung/wisatawan yang datang ke tiga obyek. Analisis pengunjung/wisatawan ini sangat penting dalam hubungannya dengan perencanaan, diversifikasi obyek wisata, daya dukung obyek, analisis kecenderungan 
(trend analysis), analisis segmentasi pasar, strategi promosi pemasaran, dan sebagainya. Cakupan analisis pengunjung/ wisatawan (Wiratno dalam Fandeli, 2000: 263) adalah sebagai berikut:

1. Pola kunjungan (trend, musiman/ bulanan)

2. Lama kunjungan (menginap, tidak menginap)

3. Distribusi spasial pengunjung (dalam negeri, luar negeri)

4. Tujuan kunjungan (rekreasi, penelitian, pendidikan)

5. Klasifikasi umur

6. Alat transportasi

Analisis pengunjung sangat baik apabila dilakukan secara berkala untuk memprediksi kecenderungan/trend yang muncul di obyek wisata. Data pengunjung yang lengkap dan komprehensif serta konsisten akan sangat diperlukan baik oleh pengelola, lembagalembaga riset, maupun pemerintah setempat untuk melakukan monitoring dan evaluasi terhadap obyek wisata. Identifikasi terhadap pengunjung obyek wisata juga bisa dijadikan gambaran kebutuhan pasar. Minat dan pola konsumsi wisatawan bisa dikontrol, ragam atraksi juga bisa dipersiapkan sejak dini, akomodasi dan sarana transportasi ditata rapi, oleh-oleh dan cinderamata menjadi menu wajib di setiap obyek.

Pola pergerakan, dan karakter wisatawan di suatu obyek wisata dapat memberikan pengaruh yang cukup kuat terhadap pariwisata secara keseluruhan. Analisis karakteristik terhadap wisatawan sangat berhubungan dengan perencanaan, diversifikasi obyek wisata, daya dukung obyek, analisis kecenderungan (trend analysis), analisis segmentasi pasar, perencanaan produk wisata, dan strategi promosi pemasaran.

\section{TINJAUAN PUSTAKA LANDASAN TEORI}

\section{Pariwisata dan Wisatawan}

Konsep pariwisata mengandung kata kunci 'perjalanan' (tour) yang dilakukan seseorang, yang melancong demi kesenangan untuk sementara waktu, bukan untuk menetap atau bekerja. Hal yang membedakan definisi wisata di masa lalu dan sekarang adalah jika di masa dulu aktivitas wisata adalah untuk kesenangan belaka, kini kegiatan wisata harus direncanakan, dilaksanakan, dan dinikmati secara serius yang kemudian mengakibatkannya menjadi tidak lagi sederhana (Pitana, 2009:12).

Pada awal perkembangannya dulu, pariwisata berkembang karena adanya gerakan manusia di dalam mencari sesuatu yang belum diketahuinya, menjelajahi wilayah yang baru, mencari perubahan suasana, atau mendapat perjalanan baru. Berawal dari definisi tersebut, lambat laun definisi pariwisata dan wisatawan semakin berkembang. Sekarang ini kata wisata diartikan sebagai perjalanan dimana si pelaku kembali ke tempat awalnya, perjalanan sirkuler yang digunakan dalam tujuan bisnis, perjalanan dengan tujuan bersenang- senang atau pendidikan dengan berbagai tempat yang dikunjungi, serta menggunakan jadwal yang terencana (Murphy, 1985:4-5 dikutip Pitana, 2005: 40-43).

Perkembangan konsep pariwisata ini membawa dampak yang sangat luas yang kemudian diikuti oleh pandangan masyarakat umum terkait isu-isu pariwisata, pelaku pariwisata, wisatawan, dan sektorsektor pendukung pariwisata seperti industri, perdagangan, penerbangan, perbankan, komunikasi, pendidikan, dan kebudayaan.

\section{Karakteristik Wisatawan}

Berbagai macam karakter/tipologi wisatawan telah dikembangkan dengan menggunakan berbagai macam klasifikasi. DAN Menurut Murphy (1985) pengklasifikasian tersebut dikelompokkan menjadi dua, yaitu atas dasar interaksi (interactional type) dan 
atas dasar kognitif-normatif (cognitivenormative models). Dasar interaksi berarti sifat-sifat interaksi antara wisatawan dengan masyarakat lokal, sedangkan dasar kognitif normatif lebih menekankan pada motivasi yang melatarbelakangi perjalanan seorang wisatawan ke suatu obyek.

Lebih lanjut, Cohen (1972) dikutip Pitana (2005:53-54) dengan pendekatan interaksi mengklasifikasikan wisatawan atas dasar tingkat familiarisasi dari daerah yang akan dikunjungi. Atas dasar ini Cohen membedakan wisatawan atas 4, yaitu: drifter, explorer, individual mass tourist, dan Organized Mass Tourist. Kemudian Smith (1977) dikutip Pitana (2005:54-55) juga membedakan karakter wisatawan menjadi beberapa klasifikasi diantaranya: Explorer, Elite, Off-beat, Unusual, Incipient mass, Mass, danCharter. Menggunakan pendekatan lain, Cohen (1979) dikutip Pitana (2005:65) mencoba membedakan tipikal wisatawan menjadi dua, modern pilgrimage (wisata ziarah modern) dan search for pleasure (mencari kesenangan). Menggunakan dua pendekatan ini, dia mengelompokkan wisatawan menjadi beberapa kelompok: Exixtensial, Experimental, Experiental, Diversionary, dan Recreational.

Beberapa tipologi yang dijabarkan oleh Smith dan Cohen di atas, terlihat penggambaran jenis-jenis wisatawan bersifat teoritis, statis dan deskriptif dengan pendekatan yang sangat makro. Kenyataan di obyek wisata sangat berbeda. Beberapa jenis wisatawan sangat mungkin tidak akan ditemukan di satu obyek wisata. Ada obyek wisata yang hanya mempunyai satu tipikal wisatawan saja misalnya. Oleh karena itu untuk tujuan perencanaan kepariwisataan di suatu obyek harus diperlukan data karakteristik wisatawan berdasarkan kebutuhan atas riil kelompok/segmentasi wisatawan bukan berdasarkan atas variabel tunggal yang bersifat linier. Tipologi wisatawan harus bersifat multi dimensional yang mengkombinasikan berbagai karakteristik

wisatawan

(Pitana, 2005:57).

Oleh karenaitu untuk tujuan perencanaan kepariwisataan di suatu obyek harus diperlukan data karakteristik wisatawan berdasarkan kebutuhan atas riil kelompok/ segmentasi wisatawan bukan berdasarkan atas variabel tunggal yang bersifat linier. Tipologi wisatawan harus bersifat multi dimensional yang mengkombinasikan berbagai karakteristik wisatawan (Pitana, 2005:57).

\section{Segmentasi Wisatawan}

Aktivitas pemasaran merupakan penghubung antara produsen dan konsumen, dalam hal ini antara penyedia jasa pariwisata dengan wisatawan. Hubungannya dengan perencanaan produk maka segmentasi pasar merupakan langkah penting yang harus dilakukan. Pemahaman konteks pariwisata, pasar adalah wisatawan, maka segmentasi pasar merupakan proses pengolongan konsumen ke dalam kelompok-kelompok berdasarkan kebutuhan yang berbeda, karakteristik, dan perilaku dimana setiap kelompok bisa dipilih sebagai pasar sasaran yang akan diraih dengan startegi bauran pemasaran tertentu (Kotler dan Keller, 2009).

Setiap wisatawan mempunyai kebutuhan yang berbeda-beda. Dengan kebutuhan, harapan, dan perilaku yang berbeda itu akan berpengaruh terhadap pilihan-pilihan / preferensi wisatawan dalam memilih produk pariwisata yang diinginkan. Pilihan-pilihan tersebut terkait dengan apa yang akan dinikmati, dikonsumsi, dan digunakan dalam rangka menghabiskan leisure di obyek wisata.

Persaingan yang ketat antar penyedia jasa pariwisata mengakibatkan para perencana pariwisata harus melihat pasar wisatawan yang tidak dilihat oleh competitor. Penyedia jasa pariwisata harus mampu melihat kebutuhan wisatawan dari 
berbagai sisi seperti geografis, demografis, psikografis, dan tingkah laku. Pemahaman kompleksitas yang dimiliki wisatawan akan membuat penyedia/pengelola jasa pariwisata mampu melihat peluang-peluang pasar wisatawan yang semakin tahun semakin berkembang pesat. Sehingga diharapkan dengan ini akan mampu merumuskan suatu startegi yang tepat dalam mendongkrak kualitas kunjungan wisata di suatu daerah.

Mengidentifikasi karakter wisatawan berdasarkan empat unsur segmentasi pasar akan bermanfaat untuk mengetahui kebutuhan dan karakteristik wisatawan serta memberikan arah bagi perencana pariwisata untuk memilih kelompok- kelompok yang paling menguntungkan untuk dibidik. Pengetahuan mengenai segmentasi pasar wisatawan dapat digunakan untuk merumuskan suatu produk pariwisata yang lebih market oriented sesuai dengan karakteristik wisatawan yang datang.

Hasil segmentasi wisatawan kemudian dimanifestasikan ke dalam pengembangan aktivitas wisata, atraksi yang ditawarkan, akomodasi, akses ke tujuan wisata, sarana pendukung pariwisata, dan juga komunikasi pemasaran terpadu yang efektif dan efisien. Tujuan dari semua ini adalah pengembangan yang dilakukan menjadi lebih terfokus dan terarah sehingga memungkinkan untuk perkembangan obyek wisata yang berkualitas, bermutu tinggi, dan mempunyai keberlangsungan hidup / sustainability yang panjang.

Pembagian segmentasi wisatawan menurut konsep segmentasi pasar dalam penelitian ini adalah untuk melihat bagaimana pergerakan wisatawan di suatu obyek wisata yang kemudian menjurus pada pemahaman bahwa wisatawan memiliki karakteristik perjalanan yang seragam atau beraneka ragam. Perbedaan pemaham inilah yang kemudian menjadi dasar untuk melihat segmentasi wisatawan dalam beberapa pendekatan pokok segmentasi pasar: geografis, demografis, psikografis, dan tingkah laku (James J. Spillane dalam Fandeli, 2000:204).

\section{Pengembangan Daya Tarik Wisata}

Pengembangan dapat diartikan sebagai proses membuat sesuatu menjadi berkembang dan menjadi lebih berguna, sedangkan daya tarik wisata adalah tempat, wilayah, atau segala sesuatu yang memiliki daya tarik untuk dikunjungi wisatawan atau dijadikan sasaran wisata (Pendit, 2002: 187). Jadi, pengertian pengembangan daya tarik wisata adalah memperbaiki dan meningkatkan kondisi obyek dan daya tariknya berdasarkan sumber daya atau potensi yang ada. Pengembangan obyek wisata bisa juga diartikan pengembangan produk baru yang dilakukan secara sadar dan terencana (Yoeti, 2002: 211). Pengembangan obyek wisata berdasarkan segmentasi pasar merupakan salah satu kegiatan yang termasuk dalam kegiatan pemasaran untuk menentukan target pasar yang dituju.

Pengembangan obyek wisata berdasarkan segmentasi pasar merupakan salah satu kegiatan yang termasuk dalam kegiatan pemasaran untuk menentukan target pasar yang dituju. Tedapat beberapa tujuan pokok yang diperoleh ketika kita melakukan analisis segmentasi wisatawan berdasarkan empat unsur segmentasi pasar yang dirumuskan oleh James Spillane, yaitu:

1. Mendesain produk-produk yang lebih responsif terhadap kebutuhan pasar.

2. Menganalisis pasardimana segmentasi pasarakan membantu pemasar mendeteksi siapa saja yang akan memakai produk kita.

3. Setelah menganalisis dan menguasai konsep segmentasi pasar dengan baik, akan sampai pada tahapan menemukan peluang/ide.

4. Mereka yang menguasai segmentasi 
pasar dengan baik akan paham betul mengenai konsep produk apa yang akan ditawarkan ke orang lain.

5. Menentukan strategi komunikasi yang efektif dan efisien serta memahami konsep perencanaan produk dan alternatif media yang paling sesuai. (Yoeti, 2002: 214).

\section{Segmentasi Produk Wisata Terpadu}

Middleton (2001: 122) memberikan pengertian produk wisata secara terperinci, "The tourist product to be considered as an amalgam of three main components of attraction, facilities and accessibility of the destination". Produk pariwisata menurut Middleton terdiri atas tiga komponen utama yaitu atraksi wisata, fasilitas di daerah tujuan wisata, dan akses menuju lokasi obyek wisata. Selain ketiga unsur produk wisata, seringkali ditambah satu unsur yang tidak kalah penting, yakni kelembagaan.

Kelembagaan ini berkaitan dengan ketersediaan sebuah organisasi atau orangorang yang mengurus destinasi tersebut. Ini menjadi penting karena walaupun destinasi sudah mempunyai atraksi, aksesibilitas dan amenitas yang baik, tapi jika tidak ada yang mengatur dan mengurus maka ke depannya pasti akan terbengkalai. Organisasi sebuah destinasi akan melakukan tugasnya seperti sebuah perusahaan. Mengelola destinasi sehingga bisa memberikan keuntungan kepada pihak terkait seperti pemerintah, masyarakat sekitar, wisatawan, lingkungan dan para stakeholder lainnya.

\section{METODE PENELITIAN}

Penelitian ini merupakan jenis penelitian kuantitatif dengan metode penelitian survei. Lokasipenelitian berada di tiga obyek wisata, yakni Pantai Goa Cemara, Pantai Kuwaru, dan Pantai Pandansimo Baru. Penelitian ini diawali dengan membuat konsep tentang survei karakteristik wisatawan di obyek wisata dengan memperhatikan unsur-unsur segmentasi wisatawan. Langkah-langkah selanjutnya adalah menyusun kuesioner, menentukan banyaknya sampel minimal dengan menggunakan teknik sampling, menyebar angket, kemudian menarik angket, mengedit dan melakukan koding angket, melakukan entri data pada software analisa statistik, dan melakukan analisa statistika berdasarkan kaedah statistik yang benar.

Pengambilan total sampel sebanyak 156 responden dengan margin error $8 \%$ yang dilakukan menggunakan teknik purposive sampling selama bulan Maret-April 2015 di ketiga lokasi penelitian. Pengumpulan data secara keseluruhan ditempuh dengan kuesioner, observasi lapangan, dan dokumentasi pustaka.

Setelah data terkumpul kemudian diolah dengan analisis kuantitatif menggunakan perangkat statistik, distribusi frekuensi, dan tabel silang (crosstabs).

\section{HASIL PENELITIAN}

Tingkat persebaran responden yang diambil dari ketiga lokasi penelitian dibagi secara proporsioanal menurut data kunjungan wisatawan per obyek wisata. Sebanyak $28.8 \%$ responden diambil di Pantai Goa Cemara, $25.2 \%$ diambil di Pantai Kuwaru, dan sisanya $45.9 \%$ responden diambil di Pantai Pandansimo Baru.

Perbandingan laki-laki danperempuan nyaris seimbang. Sedangkan sebaran usia responden cenderung membentuk distrbusi normal. 
Tabel 1 Distribusi umum penyebaran responden di ketiga obyek wisata

\begin{tabular}{|c|c|c|c|}
\hline \multicolumn{2}{|l|}{ Distribusi Sampel } & Frekuensi & Persentase \\
\hline \multicolumn{4}{|l|}{ Obyek Wisata } \\
\hline \multicolumn{2}{|l|}{ Pantai Goa Cemara } & 45 & $28,8 \%$ \\
\hline \multicolumn{2}{|l|}{ Pantai Kuwaru } & 39 & $25,2 \%$ \\
\hline \multirow{2}{*}{\multicolumn{2}{|c|}{$\begin{array}{l}\text { Pantai Pandansimo Baru } \\
\text { Jenis Kelamin }\end{array}$}} & 72 & $45,9 \%$ \\
\hline & & & \\
\hline \multirow[t]{2}{*}{ Pantai Goa Cemara } & Laki-laki & 22 & $48.9 \%$ \\
\hline & Perempuan & 23 & $51.1 \%$ \\
\hline \multirow[t]{2}{*}{ Pantai Kuwaru } & Laki-laki & 18 & $46.2 \%$ \\
\hline & Perempuan & 21 & $53.8 \%$ \\
\hline \multirow[t]{2}{*}{ Pantai Pandansimo Baru } & Laki-laki & 33 & $45.8 \%$ \\
\hline & Perempuan & 39 & $54.2 \%$ \\
\hline \multicolumn{4}{|l|}{ Usia } \\
\hline \multirow[t]{3}{*}{ Pantai Goa Cemara } & $<22$ & 10 & $22.2 \%$ \\
\hline & $22-60$ & 34 & $75.6 \%$ \\
\hline & $>60$ & 1 & $2.2 \%$ \\
\hline \multirow[t]{3}{*}{ Pantai Kuwaru } & $<22$ & 11 & $28.2 \%$ \\
\hline & $22-60$ & 28 & $71.8 \%$ \\
\hline & $>60$ & 0 & $0 \%$ \\
\hline \multirow[t]{3}{*}{ Pantai Pandansimo Baru } & $<22$ & 34 & $47.2 \%$ \\
\hline & $22-60$ & 37 & $51.4 \%$ \\
\hline & $>60$ & 1 & $1.4 \%$ \\
\hline
\end{tabular}

\section{Karakteristik Geografis}

Perbandingan dari sisi asal geografis wisatawan cukup berimbang. Artinya ketiga obyek wisata ini terbuka buat semua kalangan baik yang berasal dari luar dan dalam Kab. Bantul. Tidak ada hal yang mencolok atau dominan dalam segi asal geografis wisatawan. Mayoritas wisatawan berasal dari wilayah-wilayah di sekitar ketiga obyek wisata seperti Kulonprogo, Kota, Sleman, dan sedikit dari luar DIY. Selain itu secara geografis, wilayah DIY memiliki luas wilayah yang tidak terlalu luas dengan jarak tempuh yang tidak terlalu lama antara satu tempat ke tempat yang lain sehingga dapat meminimalkan waktu perjalanan. Faktor lain juga dapat disebabkan oleh kemudahan aksesibilitas seperti kondisi jalan yang menghubungkan Jawa Tengah dan Kota Yogyakarta sangat baik, kemudian tersedianya berbagai sarana trasnportasi yang menghubungkan ketiga lokasi obyek wisata tersebut.

\section{Karakteristik Sosiodemografis}

Secara umum, karakteristik sosiodemografis wisatawan yang datang ke ketiga lokasi penelitian tidak jauh berbeda, yakni memiliki jumlah proporsi wisatawan laki-laki dan perempuan yang seimbang. Jenis kelamin selalu dikaitkan dengan aspek gender, kerena terjadi diferensiasi peran sosial yang melekat pada masing- masing jenis kelamin. Kegiatan pariwisata sejatinya perbedaan jenis kelamin mempunyai pengaruh dalam pemilihan destinasi maupun 
aktivitas yang dilakukan wisatawan. Namun untuk jenis wisata missal seperti pantai hal tersebut menjadi tidak berlaku. Baik pria atau wanita sama-sama menyukai aktivitas berwisata di pantai.

Mayoritas wisatawan yang datang ke ketiga lokasi ini berusia 22-60 tahun. Pada rentang usia ini para wisatawan juga masih produktif dan lebih banyak melakukan kegiatan berwisata. Mayoritas wisatawan berpendidikan terakhir SMA. Tingkat pendidikan dapat menjadi alasan bagi orang untuk berwisata, karena pada dasarnya setiap wisatawan berkeinginan mencari dan menemukan pengalaman fisik atau psikologis sesuai minat masing-masing.

Responden terbanyak merupakan karyawanBUMN/swastadengan pendapatan bulanan Rp 1.000.000 - Rp 3.000.000 dan wisatawan yang memiliki status menikah. Aktivitas pariwisata biasanya dilakukan oleh orang-orang yang mempunyai penghasilan tetap, karena mereka sudah mampu melakukan perencanaan pengeluaran. Pada penelitian kali ini, responden yang ditemui sebagian besar sudah bekerja. Hal ini dapat disebabkan karena mereka memiliki penghasilan lebih memiliki keleluasaan dalam berbelanja jika dilihat dari sisi keuangan. Golongan yang telah bekerja mampu menghasilkan uang mereka sendiri dan mampu memutuskan untuk melakukan aktivitas pariwisata.

Terakhir, mayoritas wisatawan yang datang merupakan jenis wisatawan yang berulang/ repeater tourist, merupakan wisatawan yang bersifat kunjungan pribadi bersama keluarga atau teman, hanya menghabiskan waktu 1-2 jam selama berkunjung, dan lebih memilih menggunakan kendaraan pribadi (sepeda motor/mobil). Atraksi yang ditawarkan merupakan sesuatu yang unik dan baru dan mempunyai aksesibilitas yang cukup terjangkau sehingga wisatawan yang datang merasa perlu melakukan kunjungan ulang/repeat tour ke obyek wisata ini.

Temuan yang berbeda ada pada wisatawan di Pantai Kuwaru. Mayoritas wisatawan yang datang di sini didominasi oleh pelajar/mahasiswa, berumur di bawah 22 tahun, berstatus lajang, berpenghasilan di bawah Rp 1.000.000 dan bertipikal first comer tourist. Penjelasan yang bisa diberikan selama beberapa tahun terakhir pantai ini mengalami penyusutan wisatawan yang cukup signifikan. Abrasi besar- besaran yang terjadi di sini disertai dengan pemberitaan yang massif menyebabkan kunjungan wisatawan lambat laun mulai menurun. Apalagi muncul dua pantai di sekitarnya yang menawarkan atraksi yang lebih fresh dan bervariasi dengan pengembangan fasilitas yang lebih komplit.

Selama ini Pantai Kuwaru terkenal sebagai pusat kuliner makanan olahan hasil laut. Wisatawan yang datang ke sini bertujuan untuk makan seafood kemudian pulang ke rumah. Pola semacam ini terjadi dalam kurun waktu yang lama. Keterbatasan atraksi yang ditawarkan dan adanya abrasi bentang alam menyebabkan hasil suvei di pantai ini memunculkan wisatawan yang bertipikal first comer tourist atau datang untuk kunjungan yang pertama.

\section{Karakteristik Psikografis}

Dari hasil pengolahan tabel silang / crosstabs didapatkan hasil bahwa wisatawan yang berkunjung ke ketiga lokasi penelitian cenderung wisatawan yang berkarakter Psikosentris. Wisatawan yang datang ke ketiga obyek wisata cenderung lebih menyukai sesuatu yang sudah umum, jamak, popular, dengan frekuensi berwisata yang dominan rendah, wisatawan cenderung memilih aktivitas yang bersifat umum selama berlibur di obyek wisata, lama tinggal di obyek juga cukup singkat berkisar $1-2$ jam, serta wisatawan lebih berminat pada obyek yang telah dikembangkan dan popular. 


\section{Karakteristik Tingkah Laku}

Karakteristik tingkah laku/behaviour wisatawan yang datang ke ketiga pantai ini mayoritas berkunjung untuk rekreasi atau liburan dengan menikmati atraksi utama bentang alam/pantai. Sebagian besar wisatawan yang datang ke sini mendapatkan informasi dari teman/saudara untuk berkunjung. Mayoritas merupakan wisatawan yang bersifat kunjungan pribadi baik individu maupun bersama keluarga. Pengeluaran terbesar wisatawan yang datang ke Pantai Pandansimo Baru diperuntukan untuk produk kuliner (makan/minum) termasuk juga dalam hal pembelian oleh-oleh/cinderamata. Salah satu temuan penting di lokasi penelitian mengenai masih rendahnya tingkat belanja wisatawan selama berwisata. Mayoritas responden terbanyak mempunyai pengeluaran kurang dari $\mathrm{Rp}$ 100.000 dalam hal membelanjakan uang selama aktivitas berwisata.

\section{Aktivitas dan Pola Pergerakan Wisatawan}

Wisatawan yang datang ke ketiga lokasi penelitian mempunyai kecenderungan untuk melakukan kunjungan yang bersifat multi trip atau tidak hanya mengunjungi satu obyek wisata. Pola pergerakan pergerakan wisawatan yang terus bergerak dalam satu waktu kunjungan akan berakibat adanya koneksi atau keterkaitan antara satu obyek dengan obyek yang lain di lingkup daerah yang berdekatan (lihat gambar 1).

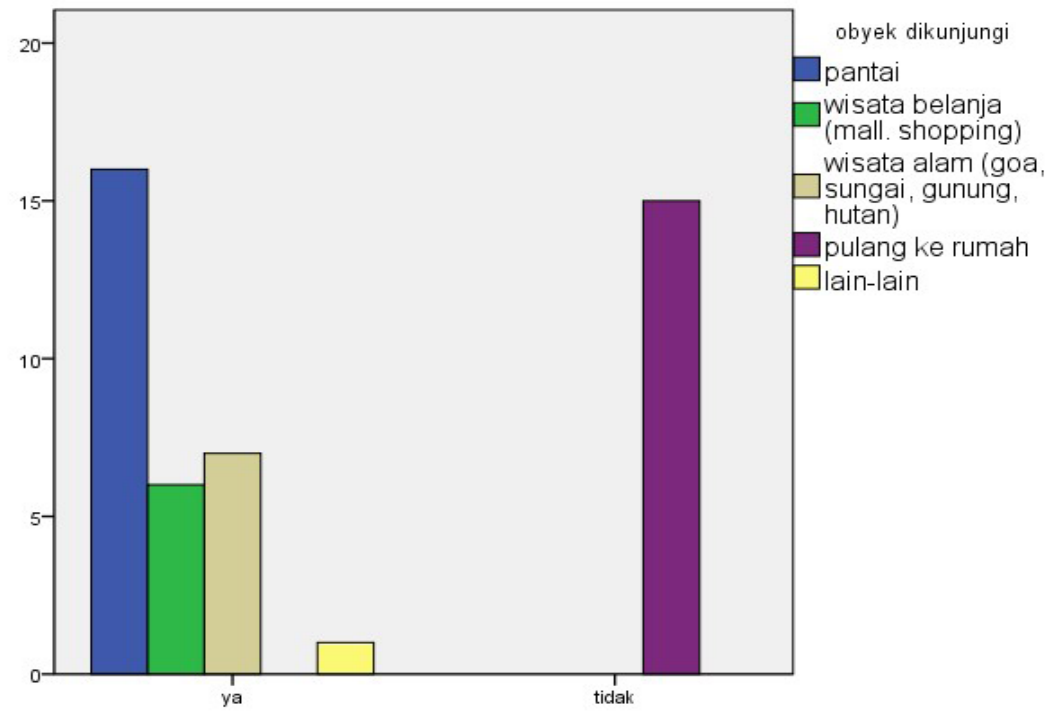

Gambar 1. Distribusi pola pergerakan wisatawan dan obyek yang dikunjungi di Pantai Goa Cemara Sumber: Data primer kuesioner, 2015

Sebagai contoh pada Gambar 1. terlihat bahwa sebanyak $66.7 \%$ atau 30 wisatawan yang datang ke Pantai Goa Cemara berpindah untuk mengunjungi obyek wisata lain setelah berkunjung ke sini. Sisanya $33.3 \%$ atau 15 wisatawan memilih pulang ke rumah masing-masing. Obyek wisata pantai menjadi pilihan yang dominan bagi wisatawan yang berkunjung ke obyek lain setelah berwisata di Pantai Goa Cemara. Sebanyak $53.3 \%$ atau 16 orang memilih pantai, $20 \%$ atau 6 orang memilih wisata belanja (shopping), $23.3 \%$ atau 7 orang memilih wisata alam (goa, hutan, sungai, 
gunung), dan $3 \%$ atau 1 orang memilih obyek wisata lain.

\section{Perencanaan Produk Pariwisata}

Hasil analisis mengenai karakteristik wisatawan di Pantai Goa Cemara, Pantai Kuwaru, dan Pantai Pandansimo Baru, didapatkan hasil bahwa secara keseluruhan karakteristik wisatawan di ketiga pantai tersebut sangat mirip. Ini harus menjadi perhatian Pemda Bantul sebagai stakeholder terkait yang mengurusi ketiga lokasi obyek wisata. Trend jumlah kunjungan wisatawan dari tahun ke tahun terus mengalami kenaikan pesat. Ketiga pantai itu menjelma menjadi sumber PAD terbesar dari sektor pariwisata setelah Pantai Parangtritis.

Ide besar yang coba dibangun adalah membuat produk pariwisata tematik berdasarkan karakteristik wisatawan dan obyek wisata masing- masing. Attraction atau atraksi adalah produk utama sebuah destinasi. Atraksi berkaitan dengan what to see dan what to do. Data kuesioner menunjukkan bahwa atraksi favorit di ketiga obyek adalah bentang alam/pantai dengan aktivitas bersantai menikmati rerimbunan pohon Cemara Udang. Mayoritas wisatawan datang juga hanya sekedar rekreasi/liburan semata. Atraksi buatan seperti sarana permainan dan hiburan, budaya masyarakat setempat, dan peninggalan bangunan bersejarah belum begitu banyak dieskplor.

Accessibility atau aksesibilitas adalah sarana dan infrastruktur untuk menuju destinasi. Akses jalan raya, ketersediaan sarana transportasi dan rambu-rambu penunjuk jalan merupakan aspek penting bagi sebuah destinasi. Ketiga pantai ini sudah ditunjang akses jalan yang sangat bagus dengan dibangunnya Jalur Jalan Lintas Selatan (JJLS). Hal yang perlu dikembangkan adalah ketersediaan saranan transportasi umum buat wisatawan yang sangat bergantung kepada sarana dan fasilitas publik.

Amenity atau amenitas adalah segala fasilitas pendukung yang bisa memenuhi kebutuhan dan keinginan wisatawan selama berada di destinasi. Amenitas berkaitan dengan ketersediaan sarana akomodasi untuk menginap serta restoran atau warung untuk makan dan minum, toilet umum, rest area, tempat parkir, klinik kesehatan, dan sarana ibadah. Secara umum kondisi amenitas di ketiga lokasi sudah cukup memadai. Poin perhatian ada pada cinderamata/oleh-oleh yang ditawarkan obyek wisata kepada wisatawan yang datang. Pengeluaran wisatawan yang datang di ketiga obyek wisata masih sangat rendah di bawah Rp 100.000. Mayoritas hanya diperuntukan dalam bentuk kuliner (makan/minum). Variasi produk cinderamata di ketiga obyek wisata harus mulai diperhatikan.

\section{KESIMPULAN}

Secara umum temuan-temuan di lapangan mengindikasikan bahwa karakteristik wisatawan di ketiga lokasi penelitian sangat mirip. Pembahasan beberapa parameter yang digunakan dalam penelitian ini menunjukkan pola yang linier mengenai karakteristik wisatawan menurut sisi geografis, sosiodemografis, psikografis, dan tingkah laku. Dari semua penjelasan sebelumnya, maka dapat ditarik beberapa kesimpulan:

Pertama, karakteristik geografis wisatawan di Pantai Goa Cemara, Pantai Kuwaru, dan Pantai Pandansimo Baru berimbang, baik yang berasal dari dalam Kabupaten Bantul maupun luar Kabupaten Bantul. Kedua, karakteristik sosiodemografis wisatawan yang datang ke Pantai Goa Cemara dan Pantai Pandansimo Baru didominasi oleh karyawan swasta/BUMN, berumur 22-60 tahun, berstatus menikah, berpenghasilan $\mathrm{Rp} \quad 1.000 .000-\mathrm{Rp}$ 3.000 .000 dan repeater tourist, sedangkan wisatawan di Pantai Kuwaru didominasi 
oleh pelajar/mahasiswa, berumur di bawah 22 tahun, berstatus lajang, berpenghasilan di bawah Rp 1.000.000 dan first comer tourist.

Ketiga, karakteristik Psikografis wisatawan yangdatangkePantaiGoaCemara, Pantai Kuwaru, dan Pantai Pandansimo Baru cenderung berkarakter Psikosentris yang menyukai sesuatu yang sudah jamak, popular, dan suka aktivitas yang bersifat umum dengan frekuensi kunjungan yang singkat. Keempat, karakteristik tingkah laku/behaviour wisatawan yang datang ke Pantai Goa Cemara, Pantai Kuwaru, dan Pantai Pandansimo Baru mayoritas berkunjung untuk rekreasi atau liburan dengan menikmati atraksi utama bentang alam/pantai serta menyukai produk kuliner sebagai oleh- oleh/cinderamata.

Kelima, pola pergerakan wisatawan di Pantai Goa Cemara, Pantai Kuwaru, dan Pantai Pandansimo Baru mayoritas berpindah mengunjungi obyek wisata lain setelah berkunjung dan lebih memilih obyek wisata pantai untuk melakukan kunjungan setelahnya. Keenam, faktor utama pendorong wisatawan untuk berkunjung ke Pantai Goa Cemara, Pantai Kuwaru, dan Pantai Pandansimo Baru banyak dipengaruhi oleh faktor sosial yang terdiri dari referensi keluarga, teman/kelompok yang berdampak pada perilaku kunjungan ke obyek wisata.

Ketujuh, motivasi utama wisatawan untuk berkunjung ke Pantai Goa Cemara, Pantai Kuwaru, dan Pantai Pandansimo Baru banyak dipengaruhi oleh motivasi fisik yang menitikberatkan pada aktivitas yang menyegarkan jiwa, kegiatan rekreasi/ senang-senang, berbelanja, dan beraktifitas olahraga. Kedelapan, perencanaan produk wisata yang paling sesuai di Pantai Goa Cemara, Pantai Kuwaru, dan Pantai Pandansimo Baru difokuskan pada tiga poin yakni atraksi, amenitas, dan aksesibilitas. Perencanaan dibuat dengan memperhatikan hasil karakteristik wisatawan menurut empat unsur segmentasi dan karakteristik masingmasing obyek.

\section{DAFTAR PUSTAKA}

BPS Kabupaten Bantul. 2014. Statistik Kecamatan Sanden 2014. Bantul.

2014. Statistik

Kecamatan Srandakan 2014. Bantul.

2014. Bantul

Dalam Angka 2014. Bantul.

2014. Statistik

Daerah Kab. Bantul 2014. Bantul.

Fandeli, Chafid dan Mukhlison. 2000. Pengusahaan Ekowisata. Yogyakarta: Fakultas Kehutanan UGM dan BKSDA Yogyakarta.

Kotler, Philip dan Kevin Keller. 2009. Manajemen Pemasaran. Jakarta: Gramedia.

Middleton, Victor. 2001. Marketing in Travel and Tourism. London: ButterworthHeinemann.

Pendit, Nyoman S. 2002. Ilmu Pariwisata: Sebuah Pengantar Perdana. Jakarta Pradnya Paramita.

Pitana, I. Gde dan I Ketut Surya Diarta. 2009. Pengantar Ilmu Pariwisata. Yogyakarta: Andi Offset.

Pitana, I. Gde dan Putu G. Gayatri. 2005. Sosiologi Pariwisata. Yogyakarta: Andi Offset.

Prajarto, Nunung. 2010. Metode Survei Untuk Penelitian Komunikasi. Yogyakarta: Fisipol UGM.

Rencana Kerja Pembangunan Daerah (RKPD) DIY Tahun 2015. Rencana Pembangunan Jangka Menengah Daerah (RPJMD) DIY 2012-2025.

Yoeti, Oka. 2012. Dasar-dasar Pengertian Hospitaliti dan Pariwisata. Bandung: 


\section{PT Alumni}

Windyanti, Resty Klara. 2013. Karakteristik Tanaman Cemara Udang (Casuarina Equisetifolia) dan Pengurangan Kecepatan Angin di Pantai Goa Cemara. Ilmu Konservasi Sumberdaya Hutan UGM. 